\title{
MEDICAL MALPRACTICE AND THE CONTRACT/TORT BOUNDARY
}

\author{
P.S. ATIYAH* \\ I

\section{INTRODUCTION}

No British observer could hope to penetrate in full the complexities of American health-care provision and its relation to the medical malpractice problem; whatever the deficiencies of the British National Health Service, ${ }^{1}$ its financial and administrative structure is simplicity itself compared to that operating in the United States, and the chief characteristic of the British malpractice problem is that there is no problem. ${ }^{2}$ I take it, therefore, that my function as an English legal scholar in this symposium is not to add my own uninformed comments to the already superabundant literature on the American malpractice problem and how to reform the system, but rather to provide a detached overview of the major new American reform proposal under discussion. This proposal-to shift the control of much of the physician/patient relationship ${ }^{3}$ from tort to contract-raises some broad issues about purposes and methodology which are addressed in this article. The article begins by asking some very general questions about the nature of the distinction between contract and tort; it then asks whether the preference being expressed by many participants in this symposium for contract over tort ${ }^{4}$ is merely a preference for a legal tool, a legal methodology, designed to achieve a desired result, or whether this preference does in fact derive from any essential distinctions between contract and tort, irrespective of outcomes. The article concludes by asking why some American reformers think that private contractual means are a better way to change malpractice rules and

Copyright (C) 1986 by Law and Contemporary Problems

* Professor of English Law, St. John's College, Oxford University; Visiting Professor, Duke Law School, spring term, 1985.

1. See, e.g., Macrae, Health Care International: Better Care at One Eighth the Cost, Economist, April 28,1984 , at 17 .

2. For a general comparision of the British and American malpractice problems, see The Influence of Litigation on Medical Practice: Proceedings of a Conference Sponsored Jointly By the Royal Society of Medicine and the Royal Society of Medicine Foundation, Inc. (C. Wood ed. 1977).

3. The term "physician/patient relationship" will be used here broadly to cover the relationship between any health care provider and a patient; malpractice rules generally are based on its central paradigm.

4. See, e.g., Epstein, Medical Malpractice, Imperfect Information, and the Contractual Foundation for Medical Services, Law \& ConTEMP. Probs., Spring 1986, at 201; Havighurst, Private Reform of Tort-Law Dogma: Market Opportunities and Legal Obstacles, LaW \& Contemp. Probs., Spring 1986, at 143; O'Connell, Neo-No-Fault Remedies for Medical Injuries: Coordinated Statutory and Contractual Alternatives, Law \& Contemp. Probs., Spring 1986, at 125. 
process than publicly legislated tort changes, such as would probably occur in Britain. Differences in attitudes and methods of legal reform raise some important questions which seem to need more attention than they have hitherto received.

\section{The Shifting Contract/Tort Boundary}

The nature of the distinction between contract law and tort law has, of course, been the focal point of a great debate during the past ten or fifteen years, and some of the key issues in this debate, which are of particular relevance to the malpractice question, are summarized below. In particular, this article will ask whether the allocation of the risk of some medical mishaps truly falls within the domain of contract. First, however, it is worth noting that for several hundred years common lawyers have played around with the boundary between contract and tort. When the rules of contract law seemed to lead to unreasonable and unjust results, lawyers have simply bypassed traditional contract doctrine by invoking tort; equally, when tort law seemed unsatisfactory for this or that reason, lawyers have developed alternative lines of approach by invoking contract.

The whole of the modern common law of contract descends from the writ of assumpsit, which was in its origins a tort writ, an offshoot of the action of trespass on the case. ${ }^{5}$ It was perceived by lawyers as early as the fifteenth century that a person who was induced to rely on a promise and suffered a detriment from its nonperformance had indeed suffered damage, and that damage could be made the subject of a claim which in its origins was a purely tortious claim. ${ }^{6}$ Later, it came to be felt increasingly anomalous that no such claim was available for pure nonfeasance, and in due course that hurdle was surmounted. ${ }^{7}$ Thus (we may say), modern contract was born from tort.

In more modern times, the process of shifting from one legal category to the other has been a familiar device for bypassing legal difficulties apparently associated with one or other category. The recent history of products liability is a well known illustration of this familiar process of legal change. When privity of contract seemed an obstacle to the recognition of just claims, lawyers simply shifted to tort. ${ }^{8}$ Then, around 1960 , when tort seemed unduly restrictive because it traditionally required proof of fault, lawyers began to invoke implied warranties, at that time thought of as a contractual concept.9 Subsequently, that solution also seemed unsatisfactory, for although it disposed of the need for proof of fault, it appeared in danger of reintroducing

5. See generally A. Simpson, A History of the Common Law of Contract: The Rise of Assumpsit 199 (1975).

6. Id. at $199-229$.

7. Id. at 249-73.

8. In America, the seminal case was Macpherson v. Buick Motor Co., 217 N.Y. 382, 111 N.E. 1050 (1916); in England, it was Donoghue v. Stevenson, [1932] A.C. 562 (Scot.).

9. See, e.g., Henningsen v. Bloomfield Motors, Inc., 32 N.J. 358, 161 A.2d 69 (1960). 
the old privity problem. So lawyers once again shifted back to tort, ${ }^{10}$ this time aided by the American Law Institute's adoption of the famous section 402A of the Restatement (Second) of Torts.

This is very far from being an isolated episode in the history of the common law. For instance, contractual liability for misrepresentation has often been used, apparently because of undue restrictions on the availability of tort, ${ }^{11}$ and there seems little doubt that many modern extensions of liability in tort are designed to overcome perceived restrictions on liability in contract, such as the need for consideration. ${ }^{12}$ Indeed, there is a sense in which much of the modern law of negligence-most of which originally applied to relationships of a consensual character-grew out of the desire of the courts to recognize that many plaintiffs were entitled to reasonable care, even where they had not paid for it. ${ }^{13}$ Such a judicial view has obvious implications for standards of medical care.

It is against this background that one must understand the modern controversies concerning the relationship between contractual and tortious liability, including liability for malpractice. While Grant Gilmore stirred enormous interest with the publication of his Death of Contract in 1974, few critics or reviewers appeared to grasp the thrust of his central argument. 14 What Gilmore was saying was that contract law had three, rather than one, basic grounds of liability. Contrary to the definitions in the Restatement (Second) of Contracts and the fundamental starting point of most contract scholars, contract law had ceased to be concerned merely with the enforcement of promises. Contract law was also concerned with the protection of detrimental reliance (bargained for or not) and the prevention of unjust enrichment (bargained for or not). In his characteristically

10. See, e.g., Greenman v. Yuba Power Products, Inc., 59 Cal. 2d 57, 377 P.2d 897, 27 Cal. Rptr. 697 (1963); Austin v. Ford Motor Co., 86 Wis. 2d 628, 273 N.W.2d 233 (1978); see also R. EPSTEIN, Modern Products Liability 32-34, 37-39 (1980).

11. In English law the outstanding example was the invention of the agent's "implied warranty of authority" in Collen v. Wright, (1857) 8 E. \& B. 647, 120 Eng. Rep. 241, a decision which spawned a huge progeny. See Atiyah, Misrepresentation, Warranty and Estoppel, 9 Alberta L. Rev. 347 (1971). The contractual nature of the agent's warranty is also recognized in American law, see RESTATEMENT (SECOND) OF AGENCY, $\$ \$ 329-30 \&$ comment c (1957), although $\$ 330$ permits an alternative action in tort.

12. Modern English examples include Hedley Byrne \& Partners Ltd. v. Heller \& Partners Ltd., [1964] A.C. 465 (liability in tort for misrepresentation affirmed in principle where defendant bank negligently gave gratuitous information as to credit of third party); Yianni v. Edwin Evans \& Sons [1982] Q.B. 438 (mortgagee's valuer who negligently failed to detect serious flaws in mortgaged premises held liable to mortgagor in tort); Ross v. Caunters [1980] Ch. 297 (solicitor who negligently omitted to advise testator as to attestation requirements liable in tort to disappointed beneficiary). For comparable American cases, see Rhode Island Hosp. Trust Nat'l Bank v. Swartz, Bresenoff, Yarner \& Jacobs, 455 F.2d 847 (4th Cir. 1972); Williams v. Polgar, 391 Mich. 6, 215 N.W.2d 149 (1974).

13. Thus, negligence law is essentially designed to be redistributive; the fact that a defendant owes a "duty" to be careful even where he has not been paid mirrors the doctrine of consideration idea that nobody should be paid for doing what he is already obligated to do. See generally P. Atryah, ThE Rise and Fall of Freedom of Contract 501-05 (1979).

14. Compare reviews by, for example, Atiyah, Book Review, 71 Am. Pol. Sci. Rev. 636 (1977); Gorley, Book Review, 89 Harv. L. Rev. 452 (1975); Speidel, Book Review, 27 Stan. L. Rev. 1161 (1975). 
entertaining way, Gilmore prophesied that contract law was about to split in two-with the detrimental reliance side merging into tort and the benefit side presumably merging into an expanded new body of restitution law (although in fact Gilmore said very little about that half of the expected change). The implication was that the element of promise was about to disappear from contract.

This was, of course, an absurd exaggeration, but it brought into relief a very important point, namely that only a small part of the rules of contract law seemed to be about what the theory of contract law said the law was about. Traditional theory said that contract law was designed to obligate parties to perform their promises; increasingly it now began to seem clear that contract law was also about other matters. Traditionally, it had been thought that contract law was "neutral" law, in that it did not involve dependence on or the use of community values. Increasingly, it was now argued that contract law necessarily involved a heavy injection of community values into private relationships, and that only the ideology of nineteenth-century marketoriented judges had hitherto obscured this insight. ${ }^{15}$ Since Gilmore opened this debate, many modern scholars have extended it still further. Thus, traditionally, contract law was thought to be independent of distributive justice; increasingly it has come to be argued that contract law is either necessarily distributive in its implications, ${ }^{16}$ or at least that there is nothing illegitimate in using it for redistributive purposes, ${ }^{17}$ even though that needs to be done with great care if the results are not to be counterproductive. ${ }^{18}$

All this has been revolutionary stuff for the traditional contract scholar, and it has since, not surprisingly, produced its counterrevolutionary movement. That movement has two wings-the economic and the philosophical-even if the second wing sometimes seems to have only one member. That member, Professor Charles Fried, has produced his own critique of the revolutionary movement in Contract as Promise. ${ }^{19}$ Whatever its merits as a critique of the Death of Contract theorists, this book cannot provide a lot of comfort to traditional contract lawyers. Fried concedes that much of what passes for contract law cannot be properly justified on the ground that it concerns the enforcement of genuine promises. All that he insists upon is that there is a real core to contractual obligations which is genuinely promise-based. He is willing to throw to the wolves-or the revolutionaries-everything else in contract law and subject it to community values, and therefore (at least in principle) to distributive considerations.

15. See, e.g., P. Atryah, supra note 13, at 388-92; Horwitz, The Historical Foundations of Modern Contract Law, 87 HaRv. L. Rev. 917 (1974).

16. P. Atryah, supra note 13, at 329-32; Atiyah, Book Review, 95 Harv. L. Rev. 509, 524-26 (1981); Hale, Bargaining, Duress, and Economic Liberty, 43 Colum. L. Rev. 603 (1943); Kennedy, Distributive and Paternalist Motives in Contract and Tort Law, With Special Reference to Compulsory Terms and Unequal Bargaining Power, 41 MD. L. Rev. 563, 609 (1982).

17. Kronman, Contract Law and Distributive Justice, 89 YaLE L.J. 472, 510-11 (1980); Kennedy, supra note 16 , at $609-14$.

18. See Kennedy, supra note 16, at 613-14.

19. See C. Fried, Contract as Promise: A Theory of Contractual Obligation (1981). 
This implies that very few contractual obligations can be justified on a strictly promissory theory of liability. ${ }^{20}$ For present purposes, the most important aspect of Fried's defense of traditional theory is that he does not even try to argue that legal rules as to unforeseen and accidental occurrences such as malpractice can properly be based on promissory liability. ${ }^{21}$

The economic wing of the counterrevolutionary movement seems to be more prolific and more strongly supported than the philosophical wing; ${ }^{22}$ but economists, of course, do not claim to tell us about justice-but only about efficiency. Even as to matters of efficiency, however, it might have been supposed that the critics of traditional contract theory had raised questions demanding answers, or at least examination. ${ }^{23}$ Economics postulates that private contracts are socially efficient because they consist of free voluntary exchanges of promises by parties who are assumed to act rationally in their own best interests. But if Gilmore and his successors are correct, contract law also enforces other obligations not derived from promises at all. At the very least, some economic answer is surely needed to the basic argument that much contractual liability does not derive from promises but is inspired by community-devised obligations. For if many contractual obligations are not based on promises, where is the presumptive efficiency of the enforcement of contracts?

\section{A. Medical Malpractice: The Case for Contract Reviewed}

Against the above background, it is now appropriate to ask what lies behind the desire to shift much control of the physician/patient relationship from tort to contract. Is there some "real" essence to this relationship which makes it "genuinely" contractual? Or, coming down from the metaphysical clouds, is contract law a more appropriate instrument as a matter of substance for controlling this relationship? Or is this merely one further episode in the historical process described above, a matter of just selecting a new legal tool or methodology to overcome doctrinal obstacles to some goals that are associated with another tool or methodology?

Perhaps the place to start is to ask why the relationship of physician and patient fell into the maw of tort law in the first place. After all, the relationship is, in most cases, rooted in a straightforward purchase of services,

20. Atiyah, Book Review, 95 Harv. L. Rev. 509, 515-28 (1981).

21. "In all of these cases [of unforeseen risks] the court is forced to sort out the difficulties that result when parties think they have agreed but actually have not. The one basis on which these cases cannot be resolved is on the basis of agreement-that is, of contract as promise. The court cannot enforce the will of the parties because there are no concordant wills. Judgment must therefore be based on principles external to the will of the parties." C. FRIED, supra note 19, at 60.

22. The literature on the economic analysis of contract law is extensive. Professor Epstein's references in this symposium make a good starting point for the interested reader. See Epstein, supra note 4 , at 102 passim.

23. See, e.g., Atiyah, The Theoretical Basis of Contract Law-An English Perspective, I INT'L REv. LAw \& ECon. 183 (1981); Kennedy \& Michelman, Are Property and Contract Efficient?, 8 Hofstra L. Rev. 711 (1980). 
and nineteenth-century lawyers would surely have seen the relationship as primarily contractual. Indeed, many other relationships which look even less contractual than that of physician/patient were moved into the area of contract law in the nineteenth century. ${ }^{24}$ In England, at least some of them (such as the attorney-client relationship) remained firmly contractual until the last few years. ${ }^{25}$

Surprisingly little attention has been given to the question why medical malpractice ever came to be dealt with as a tort. Professor Robinson suggests that it was something to do with the desire of the medical profession and of social regulators to distance the provision of medical (and possibly other professional) services from the role of ordinary commercial services. ${ }^{26}$ This distancing, in turn, he thinks had little to do with the desire to control medical malpractice by tort (that is, public) standard rather than by contract (that is, private) standards; it was more due to the desire to encourage a high degree of public deference to the profession. This argument is implausible and unconvincing. ${ }^{27}$ Certainly, the English experience suggests that different forces were at work in driving professional malpractice into tort law. For one thing the same movement occurred in England with regard to the liability of an employer to his employees, a branch of tort law which remains of much greater importance in England than in America. ${ }^{28}$

More generally, it seems clear that tort law has increasingly tended to take over almost the whole field of personal injury liability for a number of complex reasons which can only be briefly summarized here. First, there has apparently been increasing recognition that personal injuries (and fatal claims arising from accidents or misadventure) constitute a distinct social category of

24. In England, the decisive case was Boorman v. Brown, (1844) 3 Q.B. 516, aff'd, 11 Cl. \& F. 1, 8 Eng. Rep. 1003 (negligence in performance of contractual duties could be laid either in contract or in tort).

25. Thus, Groom v. Crocker [1939] 1 K.B. 194, held that a client could only sue a solicitor (attorney) for negligence by suing in contract and not in tort. This doctrine has now been held inconsistent with higher authority, Midland Bank Trust Co. v. Hett, Stubbs \& Kemp [1979] Ch. 384, but some English writers still lament that tort has been allowed as an alternative to contract in professional relationships. E.g., Kaye, The Liability of Solicitors in Tort, 100 LAW Q. REv. 680 (1984).

26. See Robinson, Rethinking the Allocation of Medical Malpractice Risks Between Patients and Providers, Law \& Contemp. Probs., Spring 1986, at 173, 180. This suggestion appears to be supported by well known cases evincing hostility to the "contract to cure" approach, e.g., Sullivan v. O'Connor, 363 Mass. 579, 296 N.E.2d 183 (1973), but these cases have always been rareties. Nobody has ever suggested that absent an express "promise to cure" contractual liability for malpractice can involve strict liability.

27. Professor Robinson offers more surmise than historical evidence. He cites P. STARR, ThE Social Transformation of American Medicine (1982) in support, but that reference bears only on the professional movement away from a commercial orientation as a cause of the shift from contract to tort. If he had cited more historical evidence for his suggestion, it might have been more persuasive.

28. Because in England workers' compensation (and later industrial injury) legislation never supplanted the tort remedy as it did in America, and because in 1948 the fellow servant rule (known in England as the doctrine of common employment) was abrogated by statute, England today has a considerable volume of personal injury litigation arising from industrial accidents. See generally $\mathbf{P}$. Atiyah, Accidents, Compensation and the Law (3d ed. 1980). 
legal problems which need to be looked at as a whole. ${ }^{29}$ It is, therefore, artificial to separate out contractual and tortious claims in this area. Second, there has been increasing belief that it ought not to make any difference to the standard of care which a patient is entitled to receive whether he did or did not pay for those services. ${ }^{30}$ This in turn may have stemmed partly from the sort of egalitarian ideology which underlay the creation of Britain's National Health Service, but the notion that a person is, as a matter of natural equity, entitled to due care from his fellow citizens without having to pay for it does not seem to be confined to egalitarian-minded Britain. Indeed it surely underlies the massive expansion of tort liability in America as well as in many other countries.

Third, there apparently has been increasing anxiety that the use of contract, rather than tort, as the source of the patient's entitlements would raise formidable problems with nonpaying patients, ${ }^{31}$ for example, babies, children, the senile, mental incompetents, and perhaps other categories. Fourth, it is possible (although it cannot be demonstrated here) that the use of tort law has been in part inspired by fear of the anomalies which would arise if the patient-physician relationship were treated as contractual, but various other medical services were supplied by means or through parties not involving any direct contractual relationship with the patient. For example, a patient may be injured by defective equipment used or supplied by his physician (drugs, vaccines) or by third parties with whom only the physician himself contracts, such as specialist consultants, hospitals, or blood suppliers.

Some of these reasons appear to remain highly relevant to the present discussion and are addressed below. First, however, the central question posed at the beginning of this section of the article will be considered. Is the physician/patient relationship inherently or essentially more of a contractual than a tortious relationship? What exactly does this mean? It could mean a number of things.

First, it could mean: Is the relationship one of more private than public interest? Many of the protagonists of the change to contract have suggested that the relationship ought to become a more private one, ${ }^{32}$ but the suggestion

29. In England this view perhaps dates back to the famous Beveridge Report, Social Insurance and Allied Services Cmd. No. 6404 (1942); see also P. AtiYah, supra note 28, at 366-68, 462-63.

30. See, e.g., Gold v. Essex County Council, [1942] 2 K.B. 293, 297 (hospital's duty of care to nonpaying patient the same as to paying patient); see also Tunkl v. Regents of the Univ. of Cal., 60 Cal. 2d 92, 103-04, 383 P.2d 441, 448, 32 Cal. Rptr. 33, 40 (1963). It should also be remembered that other consensual relationships, lacking only consideration to make them contractual, have long been treated as part of tort law in England and America, such as the relationship of occupier and (lawful) visitor.

31. As to nonpaying patients, see attempts of Scrutton, L.J. in Everett v. Griffiths, [1920] 3 K.B. 163,193 , to find that payment by the plaintiff is not necessary for the physician's implied promise to exercise reasonable care when a patient gives sufficient consideration by physically submitting to medical treatment. Cf. Gold v. Essex County Council, [1942] 2 K.B. 293, 295 (finding that it does not matter who pays the physician, because liability in tort is the same as in contract).

32. See, e.g., Epstein, Medical Malpractice: The Case for Contract, 1976 Am. B. Found. Research J. 87, 131; Havighurst, Decentralizing Decision Making: Private Contract versus Professional Norms, in MARKET Reforms in Health Care 22 (J. Meyer ed. 1983). 
suffers from being goal-inspired. The truth is that the desire to see the physician/patient relationship become more private is not an independent reason for urging the move from tort to contract; it is merely the same point being made in different language. It also seems unrealistic, if not disingenuous, to suggest that the public is ever going to cease to be vitally interested in the physician/patient relationship, even if the present massive tax bill for health care can be substantially reduced.

Alternatively, the question as to the "essential" nature of the physician/patient relationship may require that we ask whether the relationship is rooted in promissory or at least consensual elements. ${ }^{33}$ Here the protagonists of the proposed change may seem on firmer ground: surely, they may urge that promises, or at least agreements, lie at the root of the relationship. But even if the general nature of the relationship should be treated as contractual, it must be stressed here that the actual subject of this symposium is medical malpractice-claims for injury or misadventure arising out of medical treatment. These events are precisely the unforeseen and accidental by-products of a contractual relationship which cannot be accommodated within contractual theory even by a traditionalist like Professor Fried. ${ }^{34}$

The reformers are not without resource, however, for they argue that the results of malpractice are not necessarily "unforeseen," still less "unforeseeable." They are, for the most part, the perfectly foreseeable risks of various types of medical or surgical treatment. Addressing more directly some of the issues being canvassed by the reformers, such results are the foreseeable risks of omitting certain customary (but non-cost-effective) procedures. If, then, the malpractice problem really concerns foreseeable risks rather than unforeseeable accidents, argue the reformers, why can't bargaining about these risks be treated as a genuine contractual process? The argument is not without plausibility, but risk allocation cannot be seen as genuinely contractual unless both parties know of the risk. ${ }^{35}$ The question therefore becomes an empirical one: How foreseeable in reality are the risks in question to the patient and how much genuine "bargaining" over these risks can be expected? That question cannot be answered by asking in the abstract whether the physician/patient relationship is essentially or inherently contractual. Rather, it requires us to ask whether contract law is a more

33. See generally Epstein, supra note 32 .

34. C. FrIED, supra note 19; see supra text accompanying notes 19-21. Compare, however, the ingenious proposal of Jeffrey $\mathrm{O}^{\prime}$ Connell that relies on postinjury bargaining and therefore does not share this weakness of other contractual solutions. Moore \& O'Connell, Foreclosing Medical Malpractice Claims by Prompt Tender of Economic Loss, 44 LA. L. Rev. 1267 (1984); O'Connell, Offers That Can't Be Refused: Foreclosure of Personal Injury Claims by Defendants' Prompt Tender of Claimants' Net Economic Losses, 77 Nw. U.L. REv. 589 (1982). Nevertheless, O'Connell's solution is only partly contractual; it would be difficult to implement without legislative underpinning, and it attempts to solve the problem by recasting the settlement process, rather than by fundamentally changing the legal relationship between physician and patient.

35. See C. Fried, Right and Wrong 101 (1978) (condemning "the fast shuffle by which ignorance is turned into sufficient knowledge" in some economic analysis of risk-allocation bargains). 
appropriate legal category than tort law for handling malpractice claims. That is a different question and requires a different approach.

Nobody (not even a Death of Contract theorist) would dispute that contract is an appropriate legal category for regulating (perhaps within limits) many relationships found in modern societies. Modern contract law-taking that for the moment to be more or less synonymous with the law of the free market (although with a number of modern refinements)-is still the best instrument we have for handling the distribution of most goods and services. Nevertheless, the efficiency with which contract law performs this function spans a very wide spectrum and there are many reasons for thinking that the provision of medical services falls a good way from the more efficient end of the spectrum. The reasons for this should be obvious enough, but little attention seems to have been paid to most of them so far in this debate.

First, contract law works best when contracts are made by competent adults who understand what they are doing. The fact that many members of society are not competent adults gets little attention from most market oriented writers because these incompetents consume only a limited range of market goods, and in any case much of what they consume is bought for them by adults. Nevertheless, mental incompetents and some of the very old and infirm are, by definition, substantial consumers of medical services, for whom contract may be an especially inappropriate instrument. Babies and children are also consumers of health care, and it is a serious question whether the law should allow the rights of children to tort standards of medical care to be bargained away on their behalf by adults. Contract law does not seem to have faced this precise question, but traditional texts suggest that only a major upheaval in contract law could lead to an affirmative answer. ${ }^{36}$ Thus, at one stroke, almost twenty-seven percent of the American population, or some $62,000,000$ persons under the age of eighteen may be placed outside the scope of this reform. ${ }^{37}$ At the very least, it cannot be said that contract law is a more obviously appropriate way than tort law of regulating liabilities to children and babies.

Second, there are the familiar problems of lack of information, inability to evaluate risk, and inequality of bargaining power. The reformers' answer to this appears to be that employers or unions, bargaining on behalf of employees, can be expected to be as knowledgeable as the health care providers themselves. ${ }^{38}$ Patients who give up or modify their tort rights will thus be protected by the employer's knowledge even if they themselves do not really understand what they are doing. The analogy of collective bargaining

36. See, e.g., E. Farnsworth, Contracts 4.4-4.5 (1982). It is even doubtful that continued use of medical services after coming of age would bind a minor by "ratification." Medical care can sometimes be a "necessary," so that a minor who contracts for such care may have to pay for it, but this is a restitutionary, not a contractual liability, and thus could not alter the patient's legal rights against the physician.

37. U.S. Bureau of the Census, Statistical Abstract of the United States 1984, at 33 (104th ed. 1983).

38. See, e.g., Havighurst, supra note 32 , at 39-41. 
agreements in the employment field is expressly relied on. ${ }^{39}$ The problem with this answer is that it effectively undermines one of the chief aims of the reformers, as well as one of their principal arguments.

The real market enthusiasts appear to envisage a situation in which a competitive market offers a range of benefit and risk packages suitable to the individual desires, risk-averseness, and wallets of various patients. ${ }^{40}$ If all the bargaining is in practice to be done collectively (by employers and unions whose interests of course are not always identical with those of employees), however, the reality is that the rules which will govern the physician/patient relationship will not be tailored to the individual patient's needs at all. They will be fixed by third parties, just as much as the tort rules are. There may, it is true, be more choice available in the market, but this argument takes us back to our starting point about information, risk evaluation, and bargaining power. If the patient does not understand the differences in the packages offered to him, choice by itself means little, and the presumption of efficiency in outcome is rebutted.

A further problem to which little attention seems to have been paid concerns the long-term nature of the physician/patient relationship. If the terms are fixed at the outset of this relationship and continue to bind for years afterwards, it again seems unreal to think of these terms as truly negotiated or agreed-upon terms in relation to incidents occurring years after the terms were initially agreed to-and perhaps forgotten. If, on the other hand, the terms are changed frequently by third party negotiations, with little knowledge by the patient and with his consent perhaps even being presumed, ${ }^{41}$ the argument that this is an efficient outcome of market choices looks thin indeed.

A third reason for doubting whether contract, as the law of the market, is an appropriate legal category for health care provision must be mentioned, although there is no space to elaborate upon it here. This is the ethical position that people have a right to a decent standard of health care, and that they should not be required to pay for this as though it were an "optional extra," like whitewall tires or fancy trim. This ethical stance no doubt stems in part from the general egalitarian principles referred to earlier. It has also derived strength from Bernard Williams's well known suggestion that it is a necessary truth that the proper ground for the distribution of health care is ill

39. See, e.g., Stevens, Medical Malpractice: Some Implications of Contract and Arbitration in HMOs, 59 Milbank Mem. Fund Q./Health \& Soc'y 59, 76-82 (1981).

40. See, e.g., Epstein, supra note 32, at 95 (advocating “individuated responses" to patients' problems).

41. In Madden v. Kaiser Found. Hospitals, 17 Cal. 3d 699, 552 P.2d 1178, 131 Cal. Rptr. 882 (1976), a case relied upon by the reformers, plaintiff was held to an arbitration clause despite uncontradicted testimony that she knew nothing about it, because of the "implied authority" of the employer's board to negotiate amendments to the health care plan of which plaintiff was a member. Economic and fairness justifications for this result seem dubious at best, except for the argument that ordinary tort remedies are inefficient and unfair. 
health. ${ }^{42}$ The reformers criticize this idea on the ground that much health care provided today is not needed at all, and may indeed be medically quite useless. ${ }^{43}$ Furthermore, even with medical procedures which may have some therapeutic value, it is still necessary to decide whether the benefit exceeds the cost, and that decision can only be properly made by the patient himself, since the true value of the benefits depends on his own evaluation of them. ${ }^{44}$ These criticisms of the extreme ethical position ${ }^{45}$ may be well founded, but they do not begin to touch the ethical argument as to medical procedures which are genuinely necessary.

Hitherto, the health care available to everybody (including even indigents) has generally carried with it the same public (tort) standard of reasonable care. ${ }^{46}$ Although in practice, of course, nobody could suppose that the wealthy have not been able to obtain better quality treatment and care, the community has not had to openly face the uncomfortable idea that the law approves variations in the standards of health care according to the means of the sick. This might remain merely an uncomfortable idea if everyone started with an equal entitlement to some kind of genuinely necessary standard of medical treatment, objectively defined in some way by disinterested medical personnel themselves, ${ }^{47}$ leaving those who can pay for "optional extras" to do so if they wish. The uncomfortable may become the unacceptable, however, if it turns out that what is available as an entitlement to all is a lower than "reasonable" level of health care, and that only those who can afford it can purchase the "extra" needed to bring them up to the level of

42. See Williams, The Idea of Equality, in Philosophy, Politics And Society 110,120-22 (P. Laslett, W. Runciman \& B. Blackwell eds. 1962), reprinted in ThE ConCEPT OF EQUALTY 35, 44-45 (W. Blackstone ed. 1969); see also Outka, Social Justice and Equal Access to Health Care, 2 J. Relicious ETHICs 11, 12 (1974), reprinted in Contemporary Issues in Bioethics 352, 353 (T. Beauchamp \& L. Walters eds. 1978) (citing Williams's discussion of inequality of merit and inequality of need, and arguing that "an irrational state of affairs is held to obtain if those whose needs are the same are treated unequally, when needs are the ground of the treatment").

43. See, e.g., Robinson, supra note 26, at 176.

44. This follows from basic economic theory, of course, but it fits uneasily with the (apparently) admitted fact that a huge proportion of health care costs are devoted to prolonging patients' lives by ever decreasing increments. Does market theory adequately cope with the very difficult problems of the choices made by dying or nearly dying patients? Is it possible to be sure that even if they did have to pay the full cost of such treatments patients would not incur them? And does intergenerational equity not have something to say about health care consumers making choices, the cost of which is theoretically borne by them, but in fact will be borne by their families and heirs? On the other hand, do we really want the mortally ill (or their families) to face the appalling choice of deciding how much an extra six or twelve months of life is worth? There is an ethical and economic minefield here which the contract enthusiasts seem to have overlooked.

45. Fried, Equality and Rights in Medical Care, 6 HAstings Center ReP. 29 (1976), reprinted in Contemporary Issues in Bioethics 364 (T. Beauchamp \& L. Walters eds. 1978) (criticizing the characterization of equal access to health care as a right).

46. See, e.g., Directors of Georgetown College Hosp. v. Hughes, 130 F.2d 810, 827 (D.C. Cir. 1942); Tunkl v. Regents of the Univ. of Cal., 60 Cal. 2d 92, 103-04, 383 P.2d 441, 448, 32 Cal. Rptr. 33, 40 (1963); Malloy v. Fong, 37 Cal. 2d 356, 365-66, 232 P.2d 241, 246 (1951).

47. Of course, American practice means that physicians are not disinterested; but other health care arrangements are possible in which the medical personnel could be disinterested; indeed such arrangements largely exist in Britain and many other Western countries. 
"reasonableness." 48 Of course, the reformers will protest that this reasoning misrepresents their real position, which is that today's tort standards of "reasonable" care in fact exceed what is reasonable. Reality may be on their side, but their position will be vulnerable so long as they permit tort lawyers to define "reasonable care" in ways which they regard as simply wrong. It is anomalous to argue that tort standards of care are wrong in general and should therefore be bypassed in contract, yet to leave tort rules in place where no specific contract changes them. As elaborated below, it is also risky because consumers and judges may not share the reformers' goals.

\section{B. Underlying Motivations for the Proposed Change}

So far, reasons have been given for doubting that contract law is inherently more appropriate than tort law for handling the malpractice problem. There must, therefore, be suspicions that the desire to shift to contract resembles other instances of the change from one legal category to another in being primarily a preference for a different methodology which will produce different results. These suspicions are strengthened when one observes two important factors about the present reform movement. The first is that the pressure for change is not arising spontaneously in the market from the consumers of health care. It is coming from outsiders. ${ }^{49}$ Although some HMO's may indeed wish to "contract out" of much of tort law, that is hardly surprising and by itself does not take us very far. No doubt many others regularly faced with tort liabilities would also like to contract out of tort law if they could. Before it can be concluded that the proposed change to contract law is a response to the needs of those in the market, we are surely entitled to ask for evidence that the change is wanted by consumers. There seems a marked lack of such evidence so far. Instead, assertions (which may well be entirely correct) are made that if consumers of health care understood the issues they would want to rewrite the law of tort so far as it concerns medical malpractice. ${ }^{50}$ That assertion, however, seems a prescription for change in the law of tort, rather than for inviting escape from tort to contract.

The second factor raising doubts about the purposes of the proposed change to contract law is that reformers often betray their real goals to achieve certain ultimate results. Most of the reformers agree that the present law and practice relating to medical malpractice are unsatisfactory for many reasons. In particular, standards of health care are set too high, and with too little regard to cost; damages, especially for pain and suffering are too high and are socially wasteful; the collateral benefits rule duplicates compensation

48. For the idea that real psychic costs may be involved in forcing a community to acknowledge that its behavior conflicts with its own ideals, see G. Calabresi \& P. Bobbitt, Tragic Choices 121 22 (1978).

49. See, e.g., Havighurst, Reforming Medical Malpractice through Consumer Choice, HEALTH AFF., Winter 1984, at 63, 64 (admitting that pressure for legal change has come from law professors and economists and has so far remained an academic idea).

50. See Epstein, supra note 32, at 104. For a contrary view, see Law, $A$ Consumer Perspective on Medical Malpractice, Law \& Contemp. Probs., Spring 1986, at 305. 
for a lucky handful and adds to costs; too few people are compensated in any case, given the need to prove fault; and the legal and administrative costs of the whole system are excessive. ${ }^{51}$ Therefore, they conclude, contract would be a better instrument for regulating the physician/patient relationship.

These criticisms provide a cogent and powerful indictment of the present law and practice, but they also show the result orientation of the reformers. Moreover, it is not evident why they lead to the conclusion that we should shift from tort to contract. A change to contract might or might not change these results: it all depends on what consumers of health care want. For example, the constant reiteration of the assertion that standards of health care are "too high" and that marginal benefits are provided at "excessive" cost rests ultimately on the assumption that this is what consumers would say (or decide) if they really had a choice and had to pay the cost themselves. Very probably the reformers are right on this point, but one wonders how they would react if they turned out to be wrong. No doubt the real market enthusiast will accept the results of consumer choice, in whatever direction it leads; but one can be forgiven for suspecting that many other critics of the present system would be appalled if consumer choice led in a direction different from that expected. Indeed, that might be the moment at which many reformers would begin to notice the imperfections in the health care market, even after they have reformed it, and why there might be very good reasons for not enforcing contractual allocations of risk in this context.

A deep dilemma between reformers' goals and their means lies at the center of this reform movement and needs to be brought out into the open and squarely faced. Current tort law requires that health care providers meet the standard of "reasonable care," a formula flexible enough to provide fair and efficient solutions to negligence suits, if it is properly and intelligently applied. ${ }^{52}$ The reformers are convinced that the formula is not being properly and intelligently applied, and that the use of "customary standards" as a surrogate for standards of "reasonable care" in fact requires much higher standards than those of "reasonable care," ones that consumers in fact would not pay for if given a contractual choice.

Nevertheless, switching to contract law will not by itself change anything, for the only implication which can properly be made in a contract for health care is that the provider will abide by the tort standard of "reasonable care." To achieve their goals, therefore, the reformers must seek explicit contractual arrangements which will require different standards and consequences from

51. See, e.g., Havighurst, supra note 49, at 66-67; O'Connell, supra note 34, at 590-94. Of course, not everyone agrees with all these criticisms, even among the reformers. See, e.g., Defensive Medicine and Medical Malpractice: Hearings on S. 2501, 2502, 2503, and 2504 Before the Senate Comm. on Labor and Human Resources, 98th Cong., 2d Sess. 14 (1984) (statement of Patricia Danzon disagreeing with idea of no-fault liability for victims of medical misadventure); Danzon, Tort Reform and the Role of Government in Private Insurance Markets, 13 J. Legal. STud. 517, 530-33 (1984) (disagreeing with O'Connell as to the collateral benefits rule). Needless to say, there are also vigorous defenders of the status quo.

52. See, e.g., R. Posner, Economic Analysis of Law 69-70 (1973). 
those of tort law. This need for precise standards, however, presents a dilemma for the reformers: either they must admit that they are seeking (or hoping patients will seek) less than reasonable standards of care, less than reasonable compensation and so on, or they must insist that tort law as currently operated is simply wrong.

It may be argued that there can be more than one "reasonable" standard of care, level of compensation, and so on, depending on the price paid, but this argument, however plausible outside the law, is simply not available inside the courts and the legal system. It is judges and jurors who decide in tort cases what standards of care and what levels of compensation are "reasonable," and they have already pitched those levels far above what the reformers regard as "reasonable." Any attempt to contract out of these standards of care or levels of compensation must, therefore, raise the dilemma posed above. The reformers would presumably clamber off the first horn of the dilemma as rapidly as possible. They surely cannot be seeking (or want to be seen to be seeking) to impose lower than "reasonable" standards of care on patients. That leaves only one possible conclusion: tort law has just gone wrong in its enforcement of customary standards. But if tort law is simply wrong, the obvious solution seems to be to reform it-by legislation or by judicial abrogation or modification of the customary standard. Why leave it unreformed for patients unable to contract out of it?

There are, moreover, real dangers in leaving tort lawyers in control of the legal definition of "reasonable care," and trying to escape the consequences by switching to contract. Even contracts have to be interpreted and enforced by courts in the last resort (and it seems unlikely that arbitration will have a major impact on this position in the foreseeable future). Courts engaged in interpreting and enforcing contracts must (as all contract scholars agree) constantly rely on standards of "reasonableness" to supplement or flesh out the express contractual terms, ${ }^{53}$ and these standards of "reasonableness" can only come from tort law. However successful the reformers may be, it seems certain that very many consumers of health care will still find themselves governed by a tort rather than a contractual regime. Worse, by their refusal to address the correctness of tort standards head on, the reformers may indirectly confer added legitimacy on the existing tort standards that they so dislike. Tort ideas of "reasonableness" are therefore likely to permeate even the contractual supply of health care, and explicit modifications of tort standards of care will constantly have to face the challenge-in court and in the market-that they seek to foist lower than "reasonable" standards of care on patients. The same applies, of course, to levels of damage, modes of trial, and so on. This must throw great doubt on the viability of the contract reform strategy.

If, therefore, the reformers are correct-as they very probably are-that present standards of "reasonable care" (and levels of damages, etc.) are

53. See C. FRIED, supra note 19. 
simply unreasonable, then it seems imperative that the courts should be made to face up to this fact and undertake their own reform. If this does not happen, the reformers' chances of success look slim; but if it does happen, the contractual reform becomes unnecessary.

\section{Conclusion: Methods of Legal Change}

I have now reached the point of acknowledging the cogency of many of the criticisms of the present system of malpractice control, and of indicating agreement with many of the goals which the reformers ultimately hope to achieve. I quarrel only with the means which they wish to use. My relatively detached observation point now leads me to offer a number of concluding thoughts about the point at issue between us.

In Britain, a problem like the American malpractice crisis would probably be resolved by legislation. ${ }^{54}$ That requires a high degree of consensus on the reforms that are needed, and a polarization of opinion on the possible changes so that, in the last resort, majority decisionmaking is possible over the dissent of the minority. In the British political system, the necessary degree of consensus and polarization would probably be achieved in the first instance by appointing some kind of committee of inquiry which would be expected to make findings of fact on the nature and extent of the problem, and would then make recommendations for legislative change. After these have been fully considered by the government and its advisers, a bill would be drafted which would give effect to most of the committee's recommendations (with amendments, it may be) and the bill would be passed because the government necessarily has the support of the majority party in the legislature. ${ }^{55}$ This linear approach is no doubt a positivist way of planning and implementing legal change, a part of the Benthamite inheritance which has influenced Britain's machinery of legal change as much as its legal theory. It fits the British political system.

In the American scene, however, legislative law reform is far more difficult to achieve for a wide variety of institutional and traditional reasons, with which Americans are only too familiar. ${ }^{56}$ It is, of course, also a familiar story how at the time of the New Deal many enthusiastic reformers placed great

54. My estimate, however, is that English judges (although generally as wedded to "customary standards" as are American judges) would probably be willing to upset customary standards which seemed wildly over costly in relation to the benefits obtainable. The absence of jury trial in English tort law makes decisions on standards of care, for example, more "rational," at least in cost-benefit terms.

55. Of course, things do not always move as smoothly as this. For instance, the RePORT of THE Royal Commission on Civil liability and Compensation for Personal Injury, Cmd. No. 7054 (1978), did not result in any significant legislative reforms, probably because it failed to focus the issues with sufficient precision to enable straightforward choices to be made between alternative available strategies. See generally ACcident Compensation after Pearson, (D. Allen, C. Brown \& J. Holyoak eds. 1979); Fleming, The Pearson Report: Its "Strategy," 42 MOD. L. REv. 249 (1979).

56. Accord Fine \& Sunshine, Malpractice Reform Through Consumer Acceptance and Consumer Education: Are the New Concepts Marketable?, Law \& Contemp. ProBs., Spring 1986, at 213, 214. 
faith in the legislative machine as a way of instituting legal change, and how law reformers later became disillusioned with legislation and turned to the courts as instruments of legal change. For many years this reliance on litigation seemed a very successful strategy. American tort scholars and litigants persuaded or encouraged the courts to embark on a series of proplaintiff policies which eliminated many anomalies in tort law and also created strict products liability. Today, however, as the malpractice reformers desperately try to cut back on the result of these decades of pro-plaintiff policies, the British observer may wonder whether Americans have not fallen into the same trap as the sorcerer's apprentice. The pro-plaintiff personal injury machine which they have perfected over the past few decades is totally out of control and nobody knows how to stop it.

Adequate legislative reform today seems a distant hope; reform of tort doctrine from inside the courts seems impossible, given the pro-plaintiff tendencies of judges and juries. One might as well hope for Democratic policies from a Republican president, as pro-defendant decisions from proplaintiff judges and jurors.

So American reformers turn, as a last resort, to the law of contract, however unsatisfactory this may be as an instrument of legal change compared with legislation or appropriate changes in common law doctrine. Since contract is a last resort, perhaps the British observer might reluctantly admit at the end of the day that he would probably make the same choice, despite doubts about the viability of this reform strategy, if he shared the American difficulties about other methods of legal change. A dubious reform strategy, it must be conceded, is better than a plainly hopeless reform strategy, and that seems the position facing the American reformer today.

Nevertheless, a position of detachment from the immediate crisis encourages me to invite Americans to reflect on the reasons which lead them to such strange contortions in their desire for legal reform. Focusing on the immediate issues in the malpractice crisis seems to have led many reformers to forget that the crisis looks like yet another remake of an old movie: the first version (starring Professors Keeton and $\mathrm{O}^{\prime}$ Connell ${ }^{57}$ ) concerned auto accidents, and the second (starring Roger Traynor and the California Supreme Court ${ }^{58}$ ) concerned products liability. Now we have the third version, the malpractice crisis (starring the American Medical Association and the American Trial Lawyers Association?)-and that is being shown for the second time.

Does this scenario not suggest that there are deep and fundamental weaknesses in the whole American law of personal injuries? Furthermore,

57. See generally R. Keeton \& J. O'Connell, Basic Protection for the Traffic Victim: A Blueprint for Reforming Automobile Insurance (1965).

58. The seminal case is Greenman v. Yuba Power Products, Inc., 59 Cal. 2d 57, 377 P.2d 897, 27 Cal. Rptr. 697 (1962), but the California Supreme Court has continued to be the pace setter in products liability law, see, e.g., Barker v. Lull Engineering Co., 20 Cal. 3d 413, 573 P.2d 443, 143 Cal. Rptr. 225 (1978). 
does the failure to deal with these weaknesses on a broader front ${ }^{59}$ not suggest that there are in turn structural and institutional flaws in the American system of devising and instituting legal change? Is it not time that Americans begin to address some of these questions? One understands the immensity of the difficulties confronting the American super-reformer who seeks to improve the country's system of instituting legal change, but the price paid for the present "system" is high indeed. Some well-conceived costbenefit analysis here might not come amiss.

59. The proliferation of differing methods of compensating the victims of personal injury must surely begin to raise agonizing questions of equity. On what rational ground can a system be defended that provides such different legal regimes for persons suffering similar or identical injuries, according to whether the injuries are incurred at work, in an auto accident, from use of a defective product, from medical treatment, from use of a dangerous drug, from criminal violence or from purely "natural" causes? Yet, all the efforts of malpractice reformers are at present bent on producing change in the system of compensation for one type of injury alone. 
